\title{
KONSEP PENDIDIKAN WIRAUSAHA DAN KEMANDIRIAN Bagi ANAK PANTI ASUHAN
}

\author{
Zahid Mubarok ${ }^{1}$, Hendri Tanjung ${ }^{2}$, dan Abbas Mansur Tamam² \\ ${ }^{1}$ Sekolah Tinggi Ilmu Dakwah dan Komunikasi Islam (STIDKI) Bogor \\ ${ }^{2}$ Universitas Ibn Khaldun Bogor \\ *mujahidmujahid2016@gmail.com
}

\begin{abstract}
The problem of education in Indonesia at this time has not produced independent students. Education held in schools or other educational institutions also lacks creativity for students and has not yet produced innovative students and has not been able to motivate high learning. There are still many educational institutions that do not teach entrepreneurship education. Entrepreneurial education has not been widely invested in students from an early age. This research is qualitative research (qualitative research). The data in this study were obtained through library research (library research).) The data compiled consists of written materials that have been published in the form of books, journals and magazines as well as from the internet that have direct and indirect links with this research. Entrepreneurship education aims to form a whole person (holistic), as a person who has the character, understanding and skills as an entrepreneur, so the results are obtained awareness of the importance of values, the formation of the character of entrepreneurship into the behavior of students everyday through the learning process. An entrepreneur in his mind always tries to find, utilize, and create business opportunities that can provide benefits. Loss risk is normal because it holds the principle that a loss factor must exist. In fact, the greater the risk of loss that will be faced, the greater the profit opportunities that can be achieved. There is no loss term as long as someone does business with courage and calculation. This is what is called the entrepreneurial spirit.
\end{abstract}

Keyword: Entrepreneurship education, orphanage, independence of children

\section{Pendahuluan}

Era globalisasi dialami oleh seluruh masyarakat dunia termasuk di Indonesia. Tantangan global dengan adanya kemajuan ilmu pengetahuan dan teknologi menyebabkan terjadinya persaingan dan gerak cepat serta lebih kompetitif yang berdampak langsung bagi dunia pendidikan. Upaya peningkatan mutu pendidikan melalui reformasi pendidikan membutuhkan berbagai langkah untuk beradaptasi dengan tuntutan globalisasi.

Kebijakan pendidikan diharapkan dapat mengantisipasi keadaan persaingan global yang semakin ketat (Azahari, 2002). Globalisasi berkaitan dengan ekonomi dan 
kecenderungan-kecenderungan akademik yang merupakan bagian dari realitas abad ke21, (Philip G. Altbach, Philip G. \& Jane Knight, 2011: 290).

Permasalahan pendidikan di Indonesia saat ini belum melahirkan peserta didik yang mandiri. Pendidikan yang di selenggarakan di sekolah-sekolah atau lembaga pendidikan lainnya juga kurang melahirkan kreativitas bagi peserta didik dan belum dapat melahirkan peserta didik yang inovatif serta belum dapat memotivasi belajar yang tinggi. Masih banyak lembaga pendidikan yang tidak mengajarkan pendidikan kewirausahaan. Pendidikan wirausaha belum banyak ditanamkan bagi peserta didik sejak dini.

Pendidikan merupakan satu-satunya cara untuk melahirkan generasi bangsa yang berkualitas untuk mewujudkan kemajuan peradaban suatu bangsa. Pendidik hendaknya mencakup pengembangan seluruh aspek fitrah peserta didik; aspek spiritual, intelektual, imajinasi, fisik, dan bahasa, baik secara individual maupun kolektif; dan mendorong semua aspek tersebut berkembang ke arah kebaikan dan kesempurnaan.

Untuk itu diperlukan pola pendidikan yang dengan sengaja dirancang untuk membekali peserta didik dengan kecakapan hidup, yang secara integratif memadukan kecakapan generik dan spesifik guna memecahkan dan mengatasi problem kehidupan. Pendidikan haruslah fungsional dan jelas manfaatnya bagi peserta didik, sehingga tidak sekedar merupakan penumpukan pengetahuan yang tidak bermakna. Pendidikan harus diarahkan untuk kehidupan anak didik dan tidak berhenti pada penguasaan materi pembelajaran.

Oleh karena itu pendidikan yang berorientasi pada kecakapan hidup (life skills) menjadi sebuah alternatif pembaharuan pendidikan yang prospektif untuk mengantisipasi tuntutan masa depan. Dengan titik berat pendidikan pada kecakapan untuk hidup, diharapkan pendidikan benar-benar dapat meningkatkan taraf hidup dan martabat masyarakat.

Jumlah wirausahawan di Indonesia masih sedikit. Jumlah wirausahawan di Indonesia belum mencapai 2\% dari jumlah penduduk Indonesia seluruhnya. Eddy Cahyono Sugiarto selaku Asisten Staf Khusus Presiden Bidang Ekonomi dan Pembangunan pada artikelnya yang berjudul "Gerakan Kewirausahaan Nasional Untuk Menyebar Virus Wirausaha", menyatakan bahwa jumlah wirausahawan di Indonesia pada akhir tahun 2012 baru mencapai 1,56\%, atau sekitar 3.707.205 orang. Jumlah wirausahawan di Indonesia yang kurang dari 2\% menempatkan Indonesia sebagai negara berkembang, (Sugiyarto, 2013).

Pendidikan kewirausahaan sangat perlu untuk diadakan guna menambah jumlah wirausahawan dan mengurangi jumlah pengangguran. Selain memberikan bekal ketrampilan, pendidikan kewirausahaan juga dapat digunakan sebagai sarana untuk menanamkan nilai-nilai kewirausahaan. Melalui pendidikan kewirausahaan pula akan dapat menumbuhkan jiwa wirausaha. 


\section{Metode Penelitian}

Metode penelitian adalah cara-cara berpikir dan berbuat yang disiapkan dengan baik untuk mengadakan penelitian dan untuk mencapai tujuan suatu penelitian, (Hadi, 1993). Metode adalah cara atau teknis yang dilakukan dalam proses penelitian sedangkan penelitian adalah upaya dalam bidang ilmu pengetahuan yang dijalankan untuk memperoleh fakta-fakta dan prinsip-prinsip dengan sabar, hati-hati dan sistematis untuk mewujudkan kebenaran, (Mardalis, 2008).

Penelitian ini adalah penelitian kualitatif (qualitative research) yaitu penelitian yang secara langsung terhadap obyek yang diteliti, untuk mendapatkan data-data yang berkaitan dengan permasalahan-permasalahan yang dibahas. Metode kualitatif ini merupakan prosedur. Penelitian yang menghasilkan data deskriptif berupa kata-kata tertulis atau lisan dari orang-orang dan perilaku orang-orang yang dapat diamati, (Moleong, 2000).

Data-data dalam penelitian ini diperoleh melalui riset kepustakaan (library research). Data-data yang dihimpun terdiri atas ayat-ayat al-Qur'an dan bahan-bahan tertulis yang telah dipublikasikan dalam bentuk buku, jurnal dan majalah maupun dari internet yang memiliki kaitan langsung dan tidak langsung dengan penelitian ini.

\section{A. Pengertian Pendidikan}

\section{Hasil dan PEMbahasan}

Istilah Pendidikan, dalam bahasa Inggris "education", berakar dari bahasa Latin "educare", yang dapat diartikan pembimbing berkelanjutan (to lead forth). Jika diperluas, arti etimologis itu mencerminkan keberadaan pendidikan yang berlangsung dari generasi ke generasi sepanjang eksistensi kehidupan manusia, (Suhartono, 2008).

Arti luas, pendidikan adalah segala kegiatan pembelajaran yang berlangsung sepanjang zaman dalam segala situasi kegiatan kehidupan. Pendidikan berlangsung di segala jenis, bentuk dan tingkat lingkungan hidup, yang kemudian mendorong pertumbuhan segala potensi yang ada di dalam diri individu. Dengan kegiatan pembelajaran seperti itu, individu mampu mengubah dan mengembangkan diri menjadi semakin dewasa, cerdas, dan matang. Dalam arti sempit, pendidikan adalah seluruh kegiatan belajar yang direncanakan, dengan materi terorganisasi, dilaksanakan secara terjadwal dalam sistem pengawasan, dan diberikan evaluasi berdasar pada tujuan yang telah ditentukan. Kegiatan belajar seperti itu dilaksanakan di dalam Lembaga Pendidikan Sekolah, (Suhartono, 2008).

Pendidikan merupakan usaha membimbing dan membina serta bertanggung jawab untuk mengembangkan intelektual pribadi anak didik ke arah kedewasaan dan dapat menerapkannya dalam kehidupan sehari-hari. Pendidikan lebih mengarahkan tugasnya 
kepada pembinaan dan pembentukan sikap dan kepribadian manusia yang ruang lingkupnya meliputi pada proses mempengaruhi dan membentuk kemampuan kognitif, afektif dan psikomotor dalam diri manusia. Berbeda dengan pengajaran yang lebih menitikberatkan usahanya ke arah terbentuknya kemampuan maksimal intelektual dalam menerima, memahami, menghayati dan menguasai serta mengembangkan ilmu pengetahuan yang diajarkan, (H. M. Arifin, 1987).

Pengertian yang sederhana dan umum, pendidikan merupakan sebagai usaha manusia untuk menumbuhkan dan mengembangkan potensi-potensi pembawaan baik jasmani maupun rohani sesuai dengan nilai-nilai yang ada di dalam masyarakat dan kebudayaan. Usaha-usaha yang dilakukan yakni untuk menanamkan nilai-nilai dan norma tersebut serta mewariskannya kepada generasi berikutnya untuk dikembangkan dalam hidup dan kehidupan yang terjadi dalam suatu proses pendidikan, (Ihsan, 2008)

UU RI Nomor 20 Tahun 2003 mendefinisikan: Pendidikan sebagai usaha sadar dan terencana untuk mewujudkan suasana belajar dan proses pembelajaran sehingga peserta didik secara aktif mengembangkan potensi dirinya untuk memiliki kekuatan spiritual keagamaan, pengendalian diri, kepribadian, kecerdasan, akhlak mulia serta keterampilan yang diperlukan dirinya, masyarakat, bangsa dan Negara.

Dari definisi pendidikan di atas dapat disimpulkan bahwa pendidikan adalah proses pelatihan yang dilakukan secara terus menerus yang mampu mendewasakan dan mengubah kepribadian selain juga bertambahnya ilmu pengetahuan sehingga seseorang tersebut mandiri. Pendidikan adalah seni mengajar karena dengan mengajarkan ilmu, keterampilan dan pengalaman tertentu, orang akan melakukan perbuatan kreatif. Mendidik tidak semata-mata teknis, metodis, dan mekanis mengoperkan skill kepada anak tetapi merupakan kegiatan yang berdimensi tinggi dan berunsur seni yang bernuansa dedikasi, emosional, kasih sayang dalam upaya membangun dan membentuk kepribadian.

Dari definisi-definisi tersebut dapat ditekankan bahwa pendidikan tidak hanya sekedar menjadikan peserta didik menjadi sopan, taat, jujur, hormat ataupun hanya bermaksud agar peserta didik memiliki ilmu pengetahuan, seni dan teknologi. Pendidikan juga tidak hanya dipandang sebagai usaha pemberian informasi dan pembentukan keterampilan saja. Namun diperluas sehingga mencakup usaha untuk mewujudkan keinginan, kebutuhan dan kemampuan individu sehingga tercapai pola hidup pribadi dan sosial yang memuaskan.

\section{B. Pengertian Wirausaha}

Istilah wirausaha juga berasal dari bahasa Perancis yaitu entrepreneur yang diterjemahkan ke dalam bahasa Inggris dengan arti between taker atau go between dapat diartikan sebagai "the backbone of economy", yang adalah syaraf pusat perekonomian atau pengendali perekonomian suatu bangsa, (Hendro, 2011). Anonim menyatakan 
entrepreneur adalah orang yang mendobrak sistem ekonomi yang ada dengan memperkenalkan barang dan jasa yang baru. Orang tersebut melakukan kegiatannya melalui organisasi bisnis yang baru ataupun bisa dilakukan dalam organisasi bisnis yang sudah ada. Seorang wirausaha adalah orang yang melihat adanya peluang kemudian menciptakan sebuah organisasi untuk memanfaatkan peluang tersebut.

John J. Kao mendefinisikan kewirausahaan adalah usaha untuk menciptakan nilai melalui pengenalan kesempatan bisnis, manajemen pengambilan risiko yang tepat, dan melalui ketrampilan komunikasi dan manajemen untuk memobilisasi manusia, uang, dan bahan-bahan baku atau sumber daya lain yang diperlukan untuk menghasilkan proyek supaya terlaksana dengan baik, (Anonim. 2005).

Menurut Robert D. Hisrich, kewirausahaan adalah proses dinamis atas penciptaan tambahan kekayaan. Kekayaan diciptakan oleh individu yang berani mengambil risiko utama dengan syarat-syarat kewajaran, waktu dan atau komitmen karier atau penyediaan nilai untuk berbagai barang dan jasa. Produk dan jasa tersebut tidak atau mungkin baru atau unik, tetapi nilai tersebut bagaimanapun juga harus dipompa oleh usahawan dengan penerimaan dan penempatan kebutuhan keterampilan dan sumbersumber daya, (Basrowi, 2011).

Pendapat Robert D. Hisrich lebih lengkap dengan didefinisikan berdasarkan tiga pendekatan dari ekonom, psikolog, dan pebisnis, di antaranya: 1) Pendekatan ekonom, entrepreneur adalah orang yang membawa sumber-sumber daya, tenaga, material, dan aset-aset lain ke dalam kombinasi yang membuat nilainya lebih tinggi dibandingkan sebelumnya, dan juga seseorang yang memperkenalkan perubahan, inovasi/pembaharuan, dan suatu order/tatanan atau tata dunia baru; 2) Pendekatan psikolog, entrepreneur adalah betul-betul seorang yang digerakkan secara khas oleh kekuatan tertentu kegiatan untuk menghasilkan atau mencapai sesuatu, pada percobaan, pada penyempurnaan, atau mungkin pada wewenang mencari jalan keluar yang lain; 3) Pendekatan seorang pebisnis, entrepreneur adalah seorang pebisnis yang muncul sebagai ancaman, pesaing yang agresif, sebaliknya pada pebisnis lain sesama entrepreneur mungkin sebagai sekutu/mitra, sebuah sumber penawaran, seorang pelanggan, atau seorang yang menciptakan kekayaan sumber-sumber daya, mengurangi pemborosan, dan menghasilkan lapangan pekerjaan baru bagi orang lain yang dengan senang hati untuk menjalankannya, (Basrowi, 2011).

Pengertian kewirausahaan menurut Instruksi Presiden RI No. 4 Tahun 1995: Kewirausahaan adalah semangat, sikap, perilaku, dan kemampuan seseorang dalam menangani usaha dan atau kegiatan yang mengarah pada upaya mencari, menciptakan, menerapkan cara kerja, teknologi, dan produk baru dengan meningkatkan efisiensi dalam rangka memberikan pelayanan yang lebih baik dan atau memperoleh keuntungan yang lebih besar, (Basrowi, 2011). 
Secara sederhana arti wirausahawan (entrepreneur) adalah orang yang berjiwa berani mengambil risiko untuk membuka usaha dalam berbagai kesempatan. Berjiwa berani mengambil risiko artinya bermental mandiri dan berani memulai usaha, tanpa diliputi rasa takut atau cemas sekalipun dalam kondisi tidak pasti. Kegiatan wirausaha dapat dilakukan seorang diri atau berkelompok.

Jiwa kewirausahaan mendorong minat seseorang untuk mendirikan dan mengelola usaha secara profesional. Hendaknya minat tersebut diikuti dengan perencanaan dan perhitungan yang matang. Misalnya, dalam hal memilih atau menyeleksi bidang usaha yang akan dijalankan sesuai dengan prospek dan kemampuan pengusaha.

Pemilihan bidang usaha seharusnya disertai dengan berbagai pertimbangan, seperti minat, modal, kemampuan, dan pengalaman sebelumnya. Jika belum memiliki pengalaman sebelumnya, seseorang dapat menimba pengalaman dari orang lain. Pertimbangan lainnya adalah seberapa lama jangka waktu perolehan keuntungan yang diharapkan.

Peter F. Drucker mengatakan bahwa kewirausahaan merupakan kemampuan dalam menciptakan sesuatu yang baru dan berbeda. Pengertian ini mengandung maksud bahwa seorang wirausahawan adalah orang yang memiliki kemampuan untuk menciptakan sesuatu yang baru, berbeda dari yang lain. Atau mampu menciptakan sesuatu yang berbeda dengan yang sudah ada sebelumnya, (Kasmir, 2010).

Sementara itu, Zimmerer mengartikan kewirausahaan sebagai suatu proses penerapan kreativitas dan inovasi dalam memecahkan persoalan dan menemukan peluang untuk memperbaiki kehidupan (usaha). Pendapat ini tidak jauh berbeda dengan pendapat di atas. Artinya, untuk menciptakan sesuatu diperlukan suatu kreativitas dan jiwa inovator yang tinggi. Seseorang yang memiliki kreativitas dan jiwa inovator tentu berpikir untuk mencari atau menciptakan peluang yang baru agar lebih baik dari sebelumnya, (Kasmir, 2010).

Dari kedua pendapat di atas dapat disimpulkan bahwa kewirausahaan merupakan suatu kemampuan dalam hal menciptakan kegiatan usaha. Kemampuan menciptakan memerlukan adanya kreativitas dan inovasi yang terus-menerus untuk menemukan sesuatu yang berbeda dari yang sudah ada sebelumnya. Kreativitas dan inovasi tersebut pada akhirnya mampu memberikan kontribusi bagi masyarakat banyak.

Dari definisi kewirausahaan di atas dapat disimpulkan bahwa, kewirausahaan adalah suatu keberanian seseorang atau kelompok untuk hidup mandiri dengan memunculkan suatu usaha baru ataupun mengembangkan yang sudah ada menjadi lebih baik.

Dengan demikian pendidikan kewirausahaan adalah proses pelatihan usaha baru atau mengembangkan yang sudah ada menjadi lebih baik guna mendewasakan seseorang 
atau kelompok agar berkepribadian pemberani selain bertambahnya ilmu pengetahuan sehingga seseorang atau kelompok tersebut mampu untuk hidup mandiri.

Sampai saat ini konsep kewirausahaan masih terus berkembang. Kewirausahaan adalah suatu sikap, jiwa dan kemampuan untuk menciptakan sesuatu yang baru yang sangat bernilai dan berguna bagi dirinya dan orang lain. Kewirausahaan merupakan sikap mental dan jiwa yang selalu aktif atau kreatif berdaya, bercipta, berkarya dan bersahaja dan berusaha dalam rangka meningkatkan pendapatan dalam kegiatan usahanya.

Wirausahawan adalah orang-orang yang memiliki kemampuan melihat dan menilai kesempatan-kesempatan bisnis; mengumpulkan sumber daya-sumber daya yang dibutuhkan untuk mengambil tindakan yang tepat, mengambil keuntungan serta memiliki sifat, watak dan kemauan untuk mewujudkan gagasan inovatif ke dalam dunia nyata secara kreatif dalam rangka meraih sukses/ meningkatkan pendapatan. Intinya, seorang wirausaha adalah orang-orang yang memiliki karakter wirausaha dan mengaplikasikan hakikat kewirausahaan dalam hidupnya. Dengan kata lain, wirausaha adalah orang-orang yang memiliki jiwa kreativitas dan inovatif yang tinggi dalam hidupnya.

Kewirausahaan (entrepreneurship) muncul apabila seseorang individu berani mengembangkan usaha-usaha dan ide-ide barunya. Esensi dari kewirausahaan adalah menciptakan nilai tambah di pasar melalui proses pengombinasian sumber daya dengan cara-cara baru dan berbeda agar dapat bersaing.

Jadi, untuk menjadi wirausaha yang berhasil, persyaratan utama yang harus dimiliki adalah memiliki jiwa dan watak kewirausahaan. Jiwa dan watak kewirausahaan tersebut dipengaruhi oleh keterampilan, kemampuan, atau kompetensi. Kompetensi itu sendiri ditentukan oleh pengetahuan dan pengalaman usaha. Seperti telah dikemukakan di atas, bahwa seseorang wirausaha adalah seseorang yang memiliki jiwa dan kemampuan tertentu dalam berkreasi dan berinovasi. Ia adalah seseorang yang memiliki kemampuan untuk menciptakan sesuatu yang baru dan berbeda (ability to create the new and different) atau kemampuan kreatif dan inovatif. Kemampuan kreatif dan inovatif tersebut secara riil tercermin dalam kemampuan dan kemauan untuk memulai usaha (start up), kemampuan untuk mengerjakan sesuatu yang baru (creative), kemauan dan kemampuan untuk mencari peluang (opportunity), kemampuan dan keberanian untuk menanggung risiko (risk bearing) dan kemampuan untuk mengembangkan ide dan meramu sumber daya.

Wirausahawan dalam konteks manajemen adalah seseorang yang memiliki kemampuan dalam menggunakan sumber daya, seperti finansial, bahan mentah dan tenaga kerja untuk menghasilkan suatu produk baru, bisnis baru, proses produksi ataupun pengembangan organisasi. Wirausahawan adalah seseorang yang memiliki 
kombinasi unsur-unsur internal yang meliputi kombinasi motivasi, visi, komunikasi, optimisme, dorongan semangat dan kemampuan untuk memanfaatkan peluang usaha. Wirausahawan merupakan pionir dalam bisnis, inovator, penanggung risiko, yang memiliki visi ke depan dan memiliki keunggulan dalam berprestasi di bidang usaha. Kewirausahaan sebagai suatu kemampuan berpikir kreatif dan berperilaku inovatif yang dijadikan dasar, sumber daya, tenaga penggerak, tujuan siasat, kiat dan proses dalam menghadapi tantangan hidup.

Kewirausahaan (entrepreneurship) muncul apabila seseorang individu berani mengembangkan usaha-usaha dan ide-ide barunya. Proses kewirausahaan meliputi semua fungsi, aktivitas dan tindakan yang berhubungan dengan perolehan peluang dan penciptaan organisasi usaha. Esensi dari kewirausahaan adalah menciptakan nilai tambah di pasar melalui proses pengombinasian sumber daya dengan cara-cara baru dan berbeda agar dapat bersaing.

\section{Pendidikan wirausaha dalam Islam}

Konsep wirausaha dalam kaitannya dengan paradigma Islam secara filosofis yang dibangun dalam pribadi muslim terbentuknya konsepsi hubungan manusia dan lingkungannya, serta hubungan manusia dengan Tuhannya, yang dalam bahasa agama dikenal dengan istilah (hablu minnallah wa hablu minnas). Dengan berpegang pada landasan ini maka setiap muslim yang berbisnis atau beraktivitas apa pun akan merasa ada kehadiran "pihak ketiga"(Allah SWT) di setiap aspek hidupnya. Keyakinan ini menjadi bagian integral pada setiap muslim dalam berbisnis. Karena hal ini dalam Islam tidak semata - mata orientasi dunia tetapi harus mempunyai visi akhirat yang jelas.

Bekerja keras merupakan esensi dari kewirausahaan. Prinsip kerja keras, adalah suatu langkah nyata yang dapat menghasilkan kesuksesan dalam mencari rezeki, tetapi harus melalui proses yang penuh dengan tantangan Dengan kata lain, orang yang berani melewati risiko akan memperoleh peluang rezeki yang besar.

Persepsi pendidikan kewirausahaan dalam perspektif Islam menerapkan bekerja keras, Allah telah menjamin bahwa orang yang bekerja keras mencari kebutuhan dunianya dengan tetap mengindahkan kaidah-kaidah akhirat untuk memperoleh kemenangan duniawi, maka tercatat sebagai hamba Allah dengan memiliki keseimbangan tinggi. Seperti yang disampaikan seorang sosiolog besar muslim, Ibnu Khaldun dalam kitabnya, Al-Muqoddimah, menyatakan bahwa sudah menjadi watak dasar dan bawaan manusia untuk senantiasa memenuhi kebutuhan hidupnya yang telah diciptakan Allah padanya.

Untuk memenuhi kebutuhannya manusia telah diberikan dorongan naluriah untuk berusaha dan bekerja. Allah telah menghamparkan alam semesta ini untuk dimanfaatkan oleh manusia sebaik-baiknya dalam mencari rezeki. Bahkan Allah telah menjadikan manusia sebagai wakilnya, yaitu khalifah di atas bumi, untuk menjaga dan membawa 
bumi ini pada kebaikan dan kesejahteraan. Pentingnya bekerja dalam Islam, kata ma'asy merupakan keterangan tempat dari kata 'aisy (kehidupan), seakan-akan hendak dinyatakan bahwa karena 'aisy berarti hayat, maka jadilah hidup itu sebagai tempat bagi kehidupan.. Persepsi bekerja keras dalam pendidikan kewirausahaan ini sesuai dengan konsep Islam di dalamnya menekankan prinsip penghidupan ialah mencari rezeki dan berusaha untuk memperolehnya.

Berdasarkan persepsi pendidikan kewirausahaan dalam perspektif Islam, bagaimana Islam menganjurkan umatnya untuk melakukan kegiatan bisnis dengan berbagi inovasinya hal itu ditujukan untuk menjaga eksistensi seorang muslim dan akidah yang dibawanya ditengah-tengah hegemoni masyarakat global. Di samping itu, seluruh perjuangan dakwah yang diwajibkan oleh Islam tidak bisa begitu saja berjalan tanpa sokongan finansial yang kuat. Islam memberikan tempat mulia dan tinggi kepada entrepreneur muslim yang jujur lagi amanah. Jika seorang pedagang yang berusaha secara tradisional namun jujur dan amanah mendapatkan tempat yang tinggi bersama para nabi dan syuhada' dan shalihin, maka sama halnya dengan seorang entrepreneur modern yang harus mengeluarkan segala potensi yang dimilikinya untuk menggapai kesuksesan, baik potensi pemikiran, modal, fisik, waktu dan pengorbanan yang besar.

Seorang entrepreneur berpusat pada kemandirian sehingga para entrepreneur dianggap orang-orang mandiri dan berhasil sebagai pengusaha yang sukses. Definisi para pengusaha adalah orang-orang pekerja keras yang penuh inisiatif serta memiliki cita-cita atau tujuan tertentu. Fitrahnya manusia adalah pengusaha karena manusia diciptakan Allah untuk mengerahkan segenap potensinya yang dalam istilah Aa Gym disebut tukirgaya (waktu, pikiran, tenaga, biaya) meraih sukses. Dalam firmannya (QS. AlMaidah: 35), "Hai orang-orang yang beriman, bertakwalah kepada Allah dan carilah jalan yang mendekatkan diri kepada-Nya, dan berjihadlah pada jalan-Nya, supaya kamu mendapat keberuntungan".

Dalam Islam, anjuran untuk berusaha dan giat bekerja sebagai bentuk realisasi dari kekhalifahan manusia tercermin dalam QS. Ar-Ra'd (13) ayat 11 yang artinya: "Bagi manusia ada malaikat-malaikat yang selalu mengikutinya bergiliran, di muka dan di belakangnya, mereka menjaganya atas perintah Allah. Sesungguhnya Allah tidak merobah keadaan sesuatu kaum sehingga mereka merobah keadaan yang ada pada diri mereka sendiri. dan apabila Allah menghendaki keburukan terhadap sesuatu kaum, Maka tak ada yang dapat menolaknya; dan sekali-kali tak ada pelindung bagi mereka selain Dia".

Menurut al-Baghdadi bahwa ayat ini bersifat a'am. Yakni siapa saja yang mencapai kemajuan dan kejayaan bila mereka sudah mengubah sebab-sebab kemundurannya yang diawali dengan merumuskan konsepsi kebangkitan, (Wijayakusuma \& Yusanto, 2002).

\section{Tujuan Pendidikan Wirausaha}


Pendidikan kewirausahaan bertujuan untuk membentuk manusia secara utuh (holistik), sebagai insan yang memiliki karakter, pemahaman dan keterampilan sebagai wirausaha, sehingga hasilnya diperolehnya kesadaran akan pentingnya nilai-nilai, terbentuknya karakter wirausahawan ke dalam tingkah laku peserta didik sehari-hari melalui proses pembelajaran.

Di samping itu untuk melatih keterampilan berwirausaha kepada peserta didik melalui praktik berwirausaha, mendorong dan menciptakan wirausahawan baru melalui proses pembelajaran yang didukung oleh dunia usah dan industri, mitra-mitra usaha dan dinas/instansi terkait, sehingga dapat menciptakan lapangan kerja /usaha baru atau mengakses peluang kerja/usaha yang ada. Adapun tujuan pendidikan kewirausahaan antara lain:

a. Pendidikan Kewirausahaan menumbuhkan kreativitas dan inovasi

Karakter seorang anak dibangun melalui apa yang didengarkan, apa yang dilihat dan apa yang dirasakan. Pendengaran dan penglihatan adalah pintu masuk pelajaran sebelum masuk menempa hati nuraninya. Melalui seluruh indera yang manusia miliki inilah, akan muncul pembelajaran yang kuat terkait dengan apa-apa yang diterima oleh indera. Bila anak terbiasa dengan dunia wirausaha sejak kecil, maka karakter inilah yang akan muncul kelak ketika anak dewasa.

Berwirausaha bukan hanya dunianya orang dewasa, tetapi juga bisa menjadi bagian dari dunianya anak-anak. Bedanya, berwirausaha pada anak-anak tidak bisa dijalankan sendirian, namun membutuhkan bimbingan dan dukungan dari orang dewasa, orang tua maupun guru. Anak-anak yang mengenal dunia wirausaha sejak dini, akan mendapatkan manfaat yang besar untuk bekal masa depan kelak. Pada tahapan usia dini, anak-anak yang belajar menumbuhkan pembelajaran wirausaha akan tumbuh menjadi pribadi yang kreatif. Kreativitas yang terlatih sejak dini, termasuk melalui berbagai kegiatan kewirausahaan menjadi modal utama produktivitas dan kemandirian anak ketika dewasa nanti. Jiwa wirausaha (entrepreneurship) harus ditanamkan oleh para orang tua dan sekolah ketika anak-anak mereka dalam usia dini. Mengingat bahwa kewirausahaan ternyata lebih kepada menggerakkan perubahan mental. Jadi tak perlu dipertentangkan apakah kemampuan wirausaha itu berkat adanya bakat atau hasil dari proses pendidikan.

Pendidikan kewirausahaan pada diri anak tidak serta merta ada, akan tetapi memerlukan latihan secara bertahap. Bisa dimulai dari hal-hal kecil dalam aktivitas keseharian anak. Misalnya, membereskan mainan selesai bermain, rajin sikat gigi sebelum tidur dan membereskan tempat tidur. Ini merupakan latihan berdisiplin, bertanggung jawab dan awal pengajaran tentang kepemilikan. Latihan selanjutnya, mengajarkan anak untuk mampu mengelola uang dengan baik. Latihan yang perlu 
diajarkan bukan hanya cara membelanjakan, tapi juga menabung, sedekah dan mencari uang.

Pendidikan kewirausahaan perlu ditumbuhkan sejak dini, bukan hanya dalam dataran pembentukan kognitif dengan memberitahu anak tentang definisi kewirausahaan, manfaatnya dan caranya. Tetapi kewirausahaan dapat diintegrasikan dalam tema pembelajaran melalui kurikulum yang telah ada. Hal ini dapat dilakukan oleh guru secara kreatif pada saat pemberian materi pembelajaran yang dilakukan seraya bermain.

Menanamkan jiwa kewirausahaan kepada anak sejak dini, akan membentuk individu yang memiliki beberapa keterampilan, antara lain:

1) Managerial skill (ketrampilan manajerial),

2) Conceptual skill (merumuskan tujuan),

3) Human skill (keterampilan memahami, mengerti, berkomunikasi dan berelasi),

4) Decision making skill (keterampilan merumuskan masalah dan mengambil keputusan),

5) Time managerial skill (keterampilan mengatur dan menggunakan waktu).

b. Pendidikan Kewirausahaan Dalam Membangun Motivasi Anak

Motivasi adalah proses membangkitkan, mengarahkan dan memantapkan perilaku arah suatu tujuan. Motivasi merupakan hal yang melatar belakangi individu berbuat untuk mencapai suatu tujuan tertentu. Motivasi adalah kesediaan individu untuk mengeluarkan berbagai upaya dalam memenuhi kebutuhan-kebutuhannya. Motivasi dapat dicermati dari ketegangan yang dialami oleh individu, semakin besar ketegangannya, semakin tinggi tingkat upaya yang ditunjukkan oleh individu tersebut dalam mencapai tujuannya.

Dalam berwirausaha, peran motivasi terutama motivasi untuk berhasil menjadi sangat penting. Sebab di dalam motivasi terdapat sejumlah motif yang akan menjadi pendorong (drive atau stimulus) tercapainya keberhasilan. Apalagi di dalam motivasi berwirausaha diperlukan daya juang untuk sukses, mau belajar melihat keberhasilan orang lain, memiliki dorongan kuat untuk mengatasi semua kendala dalam berwirausaha. Oleh karena itu, untuk memahami motivasi perlu untuk memahami berbagai jenis kebutuhan. Hal itu sejalan dengan teori hierarki kebutuhan (hierarchy of needs) dari Abraham Maslow, yang terdiri dari: kebutuhan fisiologis, kebutuhan akan rasa aman, kebutuhan sosial, kebutuhan terhadap harga diri, kebutuhan akan aktualisasi.

Pengertian motivasi seperti yang dikemukakan di atas mengacu pada timbulnya dorongan. Sedangkan berwirausaha merupakan salah satu objek pekerjaan di samping pekerjaan lain, yakni pegawai negeri atau pegawai swasta. Dengan demikian motivasi berwirausaha diartikan sebagai tenaga dorongan yang menyebabkan siswa melakukan suatu kegiatan berwirausaha. Dengan demikian adanya perasaan senang yang menyertai timbulnya motivasi berwirausaha. Rangsangan-rangsangan dari objek wirausaha akan 
dapat menumbuhkan motivasi, dan motivasi yang telah tumbuh akan menjadikan sebagai dorongan dan motor untuk mencapai tujuan pemenuhan kebutuhan.

Kebutuhan ini menimbulkan dorongan atau motif untuk berbuat sesuatu. Setelah perbuatan tersebut dilakukan maka tercapai keadaan seimbang dalam diri siswa. Kebutuhan yang sudah tercapai dengan hasil baik akan memberikan kepuasan dan timbulnya rasa puas pada diri siswa akan diikuti perasaan senang. Akan tetapi keseimbangan tersebut tidak berlangsung untuk selamanya karena akan timbul ketidakseimbangan baru yang menyebabkan proses motivasi di atas diulangi. Keberhasilan usaha dalam bidang wirausaha terletak pada sejauh mana motivasi berprestasi dalam berwirausaha menjiwai usahanya. Semakin tinggi motivasi berprestasi dalam berwirausaha akan semakin menunjang keberhasilan usaha yang dicapai. Karena dengan motivasi berwirausaha yang tinggi akan mampu mengatasi kesulitan-kesulitan yang dihadapi dan akan mampu menciptakan jalan keluar dari kesulitan. Selain itu akan selalu didorong oleh pemikiran optimis, semangat kerja, ulet dan menggunakan program dalam mencapai tujuan di bidang usahanya, di mana kegiatannya tersebut dilaksanakan secara teratur dan bertanggung jawab.

Anak akan mempunyai dorongan yang kuat untuk berwirausaha apabila menaruh minat yang besar terhadap kegiatan wirausaha. Dengan adanya minat akan mendorong anak untuk melakukan suatu aktivitas tertentu, karena di dalam minat terkandung unsur motivasi atau dorongan yang menyebabkan anak melakukan aktivitas sesuai dengan tujuan. Kuatnya dorongan bagi diri seseorang dapat berubah-ubah sewaktu-waktu.

Ada beberapa faktor yang dapat mempengaruhi minat anak untuk berwirausaha, di antaranya:

1) Kemauan

Kemauan adalah suatu kegiatan yang menyebabkan seseorang mampu untuk melakukan tindakan dalam mencapai tujuan tertentu. Dengan adanya kemauan seseorang untuk mencoba berwirausaha, ini merupakan suatu hal yang baik.

2) Ketertarikan

Ketertarikan adalah perasaan senang, terpikat, menaruh minat kepada sesuatu. Saat ada ketertarikan dari diri seseorang, maka ada daya juang untuk meraih yang ingin dicapai. Dalam hal ini adalah ketertarikan untuk mau berwirausaha, maka anak tersebut mempunyai minat untuk berwirausaha.

3) Lingkungan Keluarga

Berkaitan dengan lingkungan keluarga, maka peran keluarga sangat penting dalam menumbuhkan minat anak. Orang tua merupakan pendidik pertama dan sebagai tumpuan dalam bimbingan kasih sayang yang utama. Maka orang tualah yang banyak memberikan pengaruh dan warna kepribadian terhadap seorang anak. Dengan demikian 
mengingat pentingnya pendidikan di lingkungan keluarga, maka pengaruh di lingkungan keluarga terhadap anak dapat mempengaruhi apa yang diminati oleh anak.

c. Kewirausahaan Menumbuhkan Jiwa Kerja Keras

Kerja dalam pengertian luas adalah bentuk usaha yang dilakukan manusia, baik dalam hal materi atau nonmateri, intelektual atau fisik, maupun hal-hal yang berkaitan dengan masalah keduniaan atau keakhiratan. Adapun pengertian kerja secara khusus adalah potensi yang dikeluarkan manusia untuk memenuhi tuntutan hidupnya berupa makanan, pakaian, tempat tinggal, dan peningkatan taraf hidupnya. Islam mempunyai perhatian besar terhadap kerja, baik dalam pengertiannya yang umum maupun khusus. Dalam tradisi Islam, kerja dinilai sebagai sesuatu yang paling tinggi, dan di lingkungan birokrasi pemerintah dan politik, kerja masuk dalam kategori profesi yang sulit, (Khayyath, 1994).

Islam mengajarkan bahwa seseorang tidak dapat hidup tanpa yang lain, demikian juga para pekerja terhadap yang lain. Akan tetapi, Islam tidak melarang pemberian definisi pekerja sebagai seseorang yang mencari upah, baik pekerja tetap seperti pegawai negeri (biasanya golongan ini tidak masuk dalam definisi kerja secara terminologi), pekerja di suatu perusahaan, koperasi, dagang, maupun para pekerja sebagaimana pengertian dewasa ini, serta pekerja dengan gaji yang tidak tetap dan disesuaikan dengan pekerjaannya, semisal kuli dan tukang kayu.

Dalam Islam digunakan istilah kerja keras, kemandirian (biyadihi), dan tidak cengeng. Setidaknya terdapat beberapa ayat al-Qur'an maupun Hadis yang dapat menjadi rujukan pesan tentang semangat kerja keras dan kemandirian ini, seperti; “Amal yang paling baik adalah pekerjaan yang dilakukan dengan cucuran keringatnya sendiri, 'amalurrajuli biyadihi (HR.Abu Dawud)"; "Tangan di atas lebih baik dari tangan di bawah"; "al yad al 'ulya khairun min al yad al sufla"(HR Bukhori Muslim). (dengan bahasa yang sangat simbolik ini Nabi mendorong umatnya untuk kerja keras supaya memiliki kekayaan, sehingga dapat memberikan sesuatu pada orang lain), atuzzakah. (QS An Nisa' : 77)

"Manusia harus membayar zakat (Allah mewajibkan manusia untuk bekerja keras agar kaya dan dapat menjalankan kewajiban membayar zakat)". Dalam sebuah ayat Allah mengatakan, "Bekerjalah kamu, maka Allah dan orang-orang yang beriman akan melihat pekerjaan kamu”. (QS. At Taubah: 105). Oleh karena itu, apabila shalat telah ditunaikan maka bertebaranlah kamu di muka bumi dan carilah karunia (rizki) Allah. (Q.S. alJumu'ah: 10).

Bahkan sabda Nabi, "Sesungguhnya bekerja mencari rizki yang halal itu merupakan kewajiban setelah ibadah fardlu" (HR.Tabrani dan Baihaqi). Nash ini jelas memberikan isyarat agar manusia bekerja keras dan hidup mandiri.

Bekerja keras merupakan esensi dari kewirausahaan. Prinsip kerja keras, menurut Wafiduddin, adalah suatu langkah nyata yang dapat menghasilkan kesuksesan (rezeki), tetapi harus melalui proses yang penuh dengan tantangan (reziko). Dengan kata lain, 
orang yang berani melewati risiko akan memperoleh peluang rizki yang besar. Kata rizki memiliki makna bersayap, rezeki sekaligus reziko (baca; risiko).

\section{Kurikulum Pendidikan}

Secara terminologi, istilah kurikulum digunakan dalam dunia pendidikan, dengan pengertian semula ialah sejumlah pengetahuan atau mata pelajaran yang harus ditempuh atau diselesaikan siswa guna mencapai suatu tingkatan atau ijazah.

Menurut Undang-undang Republik Indonesia Nomor 20 Tahun 2003 tentang Sistem Pendidikan Nasional dalam bab 1 pasal 1 ayat (19) mendefinisikan kurikulum adalah seperangkat rencana dan pengaturan mengenai tujuan, isi, dan bahan pelajaran serta cara yang digunakan sebagai pedoman penyelenggaraan kegiatan pembelajaran untuk mencapai tujuan pendidikan tertentu.

Kurikulum merupakan bentuk akuntabilitas lembaga pendidikan terhadap masyarakat. Setiap lembaga pendidikan, apakah lembaga pendidikan yang terbuka untuk setiap orang ataukah lembaga pendidikan khusus haruslah dapat mempertanggungjawabkan apa yang dilakukannya terhadap masyarakat. Lembaga pendidikan tersebut harus dapat memberikan "academic accountability" dan "legal accountability" berupa kurikulum. Oleh karena itu jika ada yang ingin mengkaji dan mengetahui kegiatan akademik apa dan apa yang ingin dihasilkan oleh suatu lembaga pendidikan maka ia harus melihat dan mengkaji kurikulum, (Sutarto, 2014).

Jika seseorang ingin mengetahui apakah yang dihasilkan ataukah pengalaman belajar yang terjadi di lembaga pendidikan tersebut tidak bertentangan dengan hukum maka ia harus mempelajari dan mengkaji kurikulum lembaga pendidikan tersebut.

Dalam pengertian "intrinsic" kependidikan maka kurikulum adalah jantung pendidikan. Artinya, semua gerak kehidupan kependidikan yang dilakukan sekolah didasarkan pada apa yang direncanakan kurikulum. Kehidupan pada lembaga pendidikan adalah kehidupan yang dirancang berdasarkan apa yang diinginkan kurikulum. Pengembangan potensi peserta didik menjadi kualitas yang diharapkan adalah didasarkan pada kurikulum, (Sutarto, 2014).

Proses pembelajaran yang dialami peserta didik baik di kelas, di sekolah, dan di luar sekolah dikembangkan berdasarkan apa yang direncanakan dalam kurikulum. Kegiatan evaluasi untuk menentukan apakah kualitas yang diharapkan sudah dimiliki oleh peserta didik dilakukan berdasarkan rencana yang dicantumkan dalam kurikulum. Oleh karena itu kurikulum adalah dasar dan sekaligus pengontrol terhadap aktivitas pendidikan. Tanpa kurikulum yang jelas apalagi jika tidak ada kurikulum sama sekali maka kehidupan pendidikan di suatu lembaga menjadi tanpa arah dan tidak efektif dalam mengembangkan potensi peserta didik menjadi kualitas pribadi yang maksimal.

Untuk menegakkan akuntabilitasnya maka kurikulum tidak boleh hanya membatasi diri pada persoalan pendidikan dalam pandangan perenialisme atau esensialisme. Kedua 
pandangan ini hanya akan membatasi kurikulum, dan pendidikan, dalam kepeduliannya. Kurikulum dan pendidikan tidak dapat dilepaskan dari berbagai masalah sosial yang muncul, masalah kehidupan yang berkembang di masyarakat. Kurikulum harus memperhatikan tuntutan masyarakat dan rencana bangsa untuk kehidupan masa mendatang. Problema masyarakat harus dianggap sebagai tuntutan, menjadi kepedulian dan masalah kurikulum. Apakah kurikulum bersifat mengembangkan kualitas peserta didik yang diharapkan dapat memperbaiki masalah dan tantangan masyarakat ataukah kurikulum merupakan upaya pendidikan membangun masyarakat baru yang diinginkan bangsa menempatkan kurikulum pada posisi yang berbeda.

Kurikulum merupakan "construct" yang dikembangkan untuk membangun kehidupan masa depan sesuai dengan bentuk dan karakteristik masyarakat yang diinginkan bangsa. Posisi ini bersifat konstruktif dan antisipatif untuk mengembangkan kehidupan masa depan yang diinginkan. Kurikulum seharusnya menjadi jantung pendidikan dalam membentuk generasi baru dengan memberikan kesempatan kepada peserta didik mengembangkan potensi dirinya memenuhi kualitas yang diperlukan bagi kehidupan masa mendatang. Tugas kurikulum untuk memberikan peluang kepada peserta didik mengembangkan potensi dirinya.

Secara umum fungsi kurikulum adalah sebagai alat untuk membantu peserta didik untuk mengembangkan pribadinya ke arah tujuan pendidikan. Kurikulum dengan segala aspek yang mempengaruhi peserta didik di sekolah, termasuk guru dan sarana serta prasarana lainnya. Kurikulum sebagai program belajar bagi peserta didik, disusun secara sistematis dan logis, diberikan oleh sekolah untuk mencapai tujuan pendidikan. Sebagai program belajar, kurikulum adalah cita-cita, rencana dan harapan.

Adapun fungsi kurikulum di antaranya meliputi:

1) Fungsi Persiapan, kurikulum berfungsi mempersiapkan siswa agar mampu melanjutkan studi lebih lanjut untuk jangkauan yang lebih jauh atau terjun ke masyarakat. Mempersiapkan kemampuan sangat perlu, karena sekolah tidak mungkin memberikan semua apa yang diperlukan atau semua apa yang menarik minat mereka.

2) Fungsi Integrasi, kurikulum berfungsi mendidik pribadi-pribadi yang terintegrasi. Oleh karena individu itu sendiri merupakan bagian integral dari masyarakat, maka pribadi yang terintegrasi itu akan memberikan sumbangan dalam rangka pembentukan atau pengintegrasian masyarakat.

3) Fungsi Diferensiasi, kurikulum perlu memberikan pelayanan terhadap perbedaan-perbedaan perorangan dalam masyarakat. Pada dasarnya diferensiasi akan mendorong orang berpikir kritis dan kreatif, sehingga ini akan mendorong kemajuan dalam sosial dalam masyarakat.

4) Fungsi Penyesuaian, karena individu hidup dalam lingkungan, sedangkan lingkungan tersebut senantiasa berubah dan dinamis, maka setiap individu harus mampu menyesuaikan diri secara dinamis. Dan di balik lingkungan pun 
harus disesuaikan dengan kondisi perorangan, di sinilah letak fungsi kurikulum sebagai alat pendidikan menuju individu yang well adjusted.

5) Fungsi Pemilihan, antara perbedaan dan pemilihan mempunyai hubungan yang erat. Pengakuan atas perbedaan berarti pula diberikan kesempatan bagi seseorang untuk memilih apa yang dinginkan dan menarik minatnya. Ini merupakan kebutuhan yang sangat ideal bagi masyarakat yang demokratis, sehingga kurikulum perlu diprogram secara fleksibel.

6) Fungsi Diagnostik, salah satu segi pelayanan pendidikan adalah membantu dan mengarahkan para siswa agar mereka mampu memahami dan menerima dirinya sehingga dapat mengembangkan semua potensi yang dimiliki. Ini dapat dilakukan bila mereka menyadari semua kelemahan dan kekuatan yang dimiliki melalui eksplorasi dan prognosis. Fungsi kurikulum dalam mendiagnosis dan membimbing siswa agar dapat mengembangkan potensi siswa secara optimal.

Sedangkan fungsi praksis dari kurikulum adalah meliputi :

1) Bagi sekolah yang bersangkutan yakni sebagai alat untuk mencapai tujuantujuan pendidikan yang diinginkan dan sebagai pedoman dalam mengatur kegiatan pendidikan sehari-hari.

2) Bagi sekolah yang di atasnya adalah untuk menjamin adanya pemeliharaan keseimbangan proses pendidikan.

3) Fungsi bagi masyarakat dan pemakai lulusan, adalah untuk menjamin akan tercapainya kompetensi yang diinginkan.

\section{Metode Pendidikan}

Metode atau metode berasal dari bahasa Yunani, yaitu Metha dan hodos. Metha berarti melalui atau melewati dan hodos berarti jalan atau cara. Metode berarti jalan atau cara yang harus di lalui untuk mencapai tujuan tertentu (Umar, 2001).

Sedangkan dalam bahasa inggris ada kata way dan ada kata method. Dua kata ini sering di terjemahkan cara dalam bahasa Indonesia. Sebenarnya yang lebih layak diterjemahkan cara adalah kata way itu, bukan kata method. Karena metode adalah istilah yang digunakan untuk mengungkapkan pengertian "cara yang paling tepat (efektif) dan cepat (efisien)" dalam melakukan sesuatu. Jadi, metode pendidikan adalah cara yang paling efektif dan efisien dalam pendidikan. Pengajaran yang efektif artinya pengajaran yang dapat dipahami murid secara sempurna, (Tafsir, 2008).

Dalam kamus besar bahasa Indonesia, metodologi berarti ilmu tentang metode atau uraian tentang metode. Menurut M. Arifin, Metodologi berasal dari dua kata yaitu metode dan logi. Adapun metode berasal dari dua kata yaitu meta (melalui) dan hodos (jalan atau cara), dan logi yang berasal dari bahasa Greek (Yunani) yaitu logos (akal atau ilmu), maka metodologi adalah ilmu pengetahuan tentang jalan atau cara yang harus di lalui untuk mencapai suatu tujuan. Dengan demikian, metodologi pendidikan adalah sesuatu ilmu 
pengetahuan tentang metode yang dipergunakan dalam pekerjaan mendidik (M. Arifin, 1996).

Metode pendidikan adalah pengembangan yang dilakukan dengan cara memindahkan peserta dari satu jabatan ke jabatan lainnya secara periodik untuk menambah keahlian dan kecakapannya pada setiap jabatan tersebut. Yang dimaksudkan untuk membantu peserta agar mengenal lebih mengerti tentang diri sendiri, menciptakan pengertian yang lebih mendalam di antara para peserta dan mengembangkan keahlian tiap peserta yang spesifik.

Hakekat pendidikan kewirausahaan pada dasarnya merupakan proses Pembelajaran penanaman tata nilai kewirausahaan melalui pembiasaan dan pemeliharaan perilaku dan sikap. Oleh sebab itu dalam pendidikan kewirausahaan harus berpegang pada beberapa prinsip seperti :

a. Humanistic, Setiap peserta didik merupakan manusia utuh dan memiliki potensi yang bersifat menyeluruh, baik jasmani maupun rohani. Setiap peserta didik memiliki kebutuhan seperti menurut pendapat Rouche, yaitu kebutuhan fisik (lelah), mengemukakan pendapat, dihargai, mendapatkan kejelasan, berbicara dan sebagainya. Suasana belajar yang manusiawi akan mampu melibatkan semua aspek taksonomi, baik kognitif, afektif maupun psikomotorik siswa. Suasana manusiawi yang dimaksud adalah suasana kekeluargaan, hangat, terbuka, obyektif, jujur dan bebas dari segala bentuk paksaan apa pun juga.

b. Student's Centre and Value Based's Teacher. Berdasarkan ketuntasan belajar dari setiap siswa, namun pengajar memiliki pedoman dan target dari setiap materi yang diajarkan.

c. Pengajar harus mampu membangkitkan daya kreativitas dan inovasi yang dimiliki siswa. Penampilan, sikap, kepribadian dan penguasaan pengajar akan proses Pembelajaran akan sangat menentukan keterlibatan dan keterikatan siswa dalam kegiatan belajar mengajar, sebagai tahap dari penggalian nilai-nilai kreativitas dari dalam diri siswa.

d. Metode Pembelajaran hendaknya disajikan dalam bentuk yang dapat dipahami, diresapi dan dihayati siswa. Pengajar hendaknya mampu mengubah konsep materi ke dalam bahasa siswa, atau dalam bentuk penerapan pada gejala kehidupan riilnya. Sehingga diharapkan materi sajian teoritis keilmuan dapat diubah menjadi stimulus yang merangsang aspek kognitif, afektif dan psikomotorik siswa.

\section{Evaluasi Pendidikan}

Istilah evaluasi berasal dari bahasa Inggris "evaluation", dalam bahasa Indonesia berarti "penilaian". Edwind Wand dan Gerald W. Brown mengatakan bahwa "Evaluation refer to the act or process to determining the value of something", (Sudijono, 
2007). Menurut definisi ini, evaluasi diartikan sebagai suatu tindakan atau suatu proses untuk menentukan nilai sesuatu.

Ada banyak pengertian yang disampaikan oleh para ahli berkenaan dengan evaluasi, antara lain: Asmawi Zainul mendefinisikan evaluasi sebagai suatu proses untuk mengambil keputusan dengan menggunakan informasi yang diperoleh dari pengukuran hasil belajar baik yang menggunakan instrumen tes, maupun nontes, (Yusuf, 2000).

Pengertian lainnya menyebutkan bahwa evaluasi merupakan suatu tindakan yang dilakukan oleh seorang evaluator terhadap suatu peristiwa atau kejadian yang dimaksudkan untuk menentukan nilai sesuatu, (Sudijono, 2007). Dalam arti luas, evaluasi adalah suatu proses merencanakan, memperoleh, dan menyediakan informasi yang sangat diperlukan untuk membuat alternatif-alternatif keputusan, (Yusuf, 2000).

Nurgiyantoro melengkapi pengertian di atas dengan menyebutkan bahwa evaluasi diartikan sebagai suatu proses untuk mengukur kadar pencapaian tujuan, (Yusuf, 2000). Dalam hal ini, evaluasi merupakan suatu proses untuk mengetahui apakah suatu kegiatan, atau keluaran dari suatu program itu telah sesuai dengan tujuan atau kriteria yang telah ditentukan atau belum.

Berdasarkan pengertian di atas, dapat dikatakan bahwa evaluasi adalah usaha yang dilakukan seseorang di dalam menentukan nilai sesuatu, baik secara kualitatif maupun kuantitatif, berdasarkan data informasi yang terkumpul, untuk selanjutnya dipertimbangkan melalui kegiatan mengolah/menilai data yang ada berdasarkan acuan/kriteria tertentu sehingga menjadi nilai, yang pada akhirnya digunakan untuk mengambil berbagai keputusan.

Selanjutnya, berdasarkan pengertian evaluasi di atas, secara harfiah evaluasi pendidikan dapat diartikan sebagai penilaian dalam bidang pendidikan atau penilaian mengenai hal-hal yang berkaitan dengan kegiatan pendidikan, (Sujana, 1989). Pengertian tersebut menunjuk pada adanya suatu tindakan atau kegiatan. Kegiatan yang dimaksud adalah menentukan nilai. Penilaiannya berkenaan dengan segala sesuatu yang berhubungan dengan dunia pendidikan, seperti evaluasi terhadap hasil belajar-mengajar, evaluasi terhadap materi pelajaran, evaluasi terhadap pelaksanaan pengajaran, dan lain-lain.

\section{Kemandirian}

Istilah "kemandirian" berasal dari kata dasar "diri" yang mendapat awalan "ke" dan akhiran "an", kemudian membentuk satu kata keadaan atau kata benda. Karena kemandirian berasal dari kata "diri", maka pembahasan mengenai kemandirian tidak bisa lepas dari pembahasan tentang perkembangan diri itu sendiri, yang dalam konsep Carl Rogers disebut dengan istilah self, karena diri itu merupakan inti dari kemandirian, (Desmita, 2014). 
Istilah kemandirian menunjukkan adanya kepercayaan akan sebuah kemampuan diri dalam menyelesaikan masalah tanpa bantuan dari orang lain. Individu yang mandiri sebagai individu yang dapat menyelesaikan masalah-masalah yang dihadapinya, mampu mengambil keputusan sendiri, mempunyai inisiatif dan kreatif, tanpa mengabaikan lingkungan di sekitarnya. Menurut beberapa ahli "kemandirian" menunjukkan pada kemampuan psikososial yang mencakup kebebasan untuk bertindak, tidak tergantung dengan kemampuan orang lain, tidak terpengaruh lingkungan, dan bebas mengatur kebutuhannya sendiri, (Nurhayati, 2011).

Kemandirian merupakan adanya indikasi unsur-unsur tanggung jawab, percaya diri, inisiatif, memiliki motivasi yang kuat untuk maju, demi kebaikan dirinya, mantap mengambil keputusan sendiri, tidak menggantungkan diri pada orang lain, memiliki hasrat untuk berkompetisi dengan orang lain, mampu mengatasi hambatan, melakukan sesuatu dengan tepat, gigih dalam usaha, mampu mengatur kebutuhannya sendiri, dan tegas dalam bertindak serta menguasai tugas yang diembannya.

Kemandirian merupakan suatu sikap individu yang diperoleh secara bertahap selama perkembangan berlangsung, di mana individu akan terus belajar untuk bersikap mandiri dalam menghadapi berbagai situasi di lingkungan, sehingga individu pada akhirnya akan mampu berpikir dan bertindak sendiri.

Kemandirian adalah kemampuan mengambil keputusan sendiri dengan atau tanpa bantuan orang lain, yang relevan, tetapi tidak menggantungkan diri kepada orang lain, berinisiatif untuk mengatasi masalah yang dihadapi, percaya diri dalam mengatasi tugastugas, dan bertanggung jawab atas apa yang telah dilakukan, (Nurhayati, 2011).

Kemandirian adalah kemampuan dalam mengatur tingkah laku, menyeleksi dan membimbing keputusan dan perilakunya tersebut tanpa ada paksaan serta pengontrolan dari orang tua atau pengawasan orang tua. Kemampuan tersebut berarti individu mampu mengelola potensi yang dimilikinya dan siap menerima konsekuensi dari keputusan yang diambil. Dinyatakan pula oleh Kemandirian sebagai kekuatan motivasional dalam diri individu untuk mengambil keputusan dan menerima tanggung jawab atas konsekuensi keputusan itu.

Kemandirian adalah kemampuan untuk berdiri sendiri atau menggali potensi-potensi yang ada pada dirinya, agar tidak tergantung pada orang lain, baik dalam merumuskan kebutuhan-kebutuhannya, maupun dalam mengatasi kesulitan dan tantangan yang dihadapinya serta bertanggung jawab dan berdiri sendiri.

Konsep mengenai kemandirian, yaitu mencakup kebebasan untuk bertindak, tidak bergantung kepada orang lain, tidak terpengaruh lingkungan dan bebas mengatur kebutuhan sendiri. Konsep kemandirian ialah kebebasan untuk mengambil inisiatif, mengatasi hambatan, gigih dalam usaha, dan melakukan sendiri segala sesuatu tanpa bantuan orang lain. Dengan kata lain kemandirian tersebut merupakan kemampuan 
dalam mengelola diri sehingga ia mampu mengoptimalkan semua potensi yang dimiliki dalam berusaha memenuhi kebutuhan hidupnya.

1. Ciri-ciri Kemandirian

Kemandirian secara psikososial tersusun dari tiga aspek yaitu:

a. Mandiri emosi adalah aspek kemandirian yang berhubungan dengan perubahan pendekatan atau keterkaitan hubungan emosional individu, terutama sekali dengan orang tua atau orang dewasa lainya yang banyak melakukan interaksi dengan dirinya

b. Mandiri bertindak adalah kemampuan untuk membuat keputusan secara beban, menindaklanjuti, serta bertanggung jawab.

c. Mandiri berpikir adalah kebebasan memaknai seperangkat prinsip tentang benarsalah, baik-buruk, dan apa yang berguna bagi dirinya.

2. Bentuk-bentuk Kemandirian

Robert Havighurst membedakan kemandirian atas empat bentuk kemandirian, yaitu:

a. Kemandirian Emosi

Merupakan kemampuan mengontrol emosi sendiri dan tidak tergantung kebutuhan emosi orang lain

b. Kemandirian Ekonomi

Kemandirian ekonomi yaitu kemampuan mengatur ekonomi sendiri dan tidak tergantungnya kebutuhan ekonomi pada orang lain.

c. Kemandirian Intelektual

Kemandirian intelektual yaitu kemampuan untuk mengatasi berbagai masalah yang dihadapi

d. Kemandirian Sosial

Kemandirian sosial merupakan kemampuan untuk mengadakan interaksi dengan orang lain dan tidak bergantung pada aksi orang lain (Desmita, 2014).

\section{KeSimpulan.}

Pendidikan adalah proses pelatihan yang dilakukan secara terus menerus yang mampu mendewasakan dan mengubah kepribadian selain juga bertambahnya ilmu pengetahuan sehingga seseorang tersebut mandiri. Pendidikan adalah seni mengajar karena dengan mengajarkan ilmu, keterampilan dan pengalaman tertentu, orang akan melakukan perbuatan kreatif. Mendidik tidak semata-mata teknis, metodis, dan mekanis mengoperkan skill kepada anak tetapi merupakan kegiatan yang berdimensi tinggi dan berunsur seni yang bernuansa dedikasi, emosional, kasih sayang dalam upaya membangun dan membentuk kepribadian. Dinamakan seni karena kegiatan pendidikan dilandasi oleh rasa kemanusiaan, simpati, dan kecintaan. 
Kewirausahaan adalah suatu keberanian seseorang atau kelompok untuk hidup mandiri dengan memunculkan suatu usaha baru ataupun mengembangkan yang sudah ada menjadi lebih baik.

Pendidikan kewirausahaan adalah proses pelatihan usaha baru atau mengembangkan yang sudah ada menjadi lebih baik guna mendewasakan seseorang atau kelompok agar berkepribadian pemberani selain bertambahnya ilmu pengetahuan sehingga seseorang atau kelompok tersebut mampu untuk hidup mandiri.

Seorang wirausahawan dalam pikirannya selalu berusaha mencari, memanfaatkan, serta menciptakan peluang usaha yang dapat memberikan keuntungan. Risiko kerugian merupakan hal biasa karena memegang prinsip bahwa faktor kerugian pasti ada. Bahkan, semakin besar risiko kerugian yang bakal dihadapi, semakin besar pula peluang keuntungan yang dapat diraih. Tidak ada istilah rugi selama seseorang melakukan usaha dengan penuh keberanian dan penuh perhitungan. Inilah yang disebut dengan jiwa wirausaha.

Kemandirian adalah kemampuan untuk berdiri sendiri atau menggali potensi-potensi yang ada pada dirinya, agar tidak tergantung pada orang lain, baik dalam merumuskan kebutuhan-kebutuhannya, maupun dalam mengatasi kesulitan dan tantangan yang dihadapinya serta bertanggung jawab dan berdiri sendiri.

\section{DAFTAR PUSTAKA}

Arifin, H. M. (1987). Filsafat Pendidikan Islam. Jakarta: Bina Aksara.

Arifin, M. (1996). Ilmu Pendidikan Islam. Jakarta: Bumi Aksara.

Azahari, A. (2002). Reformasi Pendidikan Menuju Indonesia Baru. Jurnal Pendidikan dan Kebudayaan, 6(25).

Basrowi. (2011). Kewirausahaan untuk Perguruan Tinggi (Cet.1). Bogor: Ghalia Indonesia.

Desmita. (2014). Psikologi Perkembangan Peserta Didik. Bandung: PT. Remaja Rosdakarya.

Hadi, S. (1993). Metodologi Research (Vol. II,). Yogyakarta: Yayasan Penerbit Fak. Psikologi UGM.

Hendro. (2011). Dasar-Dasar Kewirausahaan. Panduan bagi Mahasiswa untuk Mengenal, Memahami, dan Memasuki Dunia Bisnis. Jakarta: Erlangga.

Ihsan, F. (2008). Dasar- Dasar Kependidikan: Komponen MKDK. Jakarta: Rineka Cipta. Kasmir. (2010). Kewirausahaan (Cet. 5). Jakarta: RajaGrafindo Persada.

Khayyath, A. A. Al. (1994). Etika Bekerja Dalam Islam. Jakarta: Gema Insani Press. Mardalis. (2008). Metode Penelitian: Suatu Pendekatan Proposal. Jakarta: Bumi Aksara. Moleong, L. L. J. (2000). Metodologi Penelitian Kualitatif, Cet. Ke 13. Bandung: Remaja Rosdakarya.

Nurhayati, E. (2011). Psikologi Pendidikan Inovatif. Yogyakarta: Pustaka Pelajar. Sudijono, A. (2007). Pengantar Evaluasi Pendidikan. Jakarta: Raja Grafindo Persada. Sugiyarto, E. C. (2013). Gerakan Kewirausahaan Nasional Untuk Menyebar Virus 
Wirausaha'. Diambil dari http://www.setkab.go.id/artikel-7434.html Suhartono. (2008). Filsafat Pendidikan (Cet. III). Jogjakarta: Ar-Ruzz Media. Sujana, N. (1989). Penilaian Hasil Proses Belajar Mengajar. Bandung: Remaja Rosda Karya.

Sutarto, L. N. (2014). Kurikulum dan Pembelajaran dalam Implementasi pada Kurikulum 2013. Jakarta: CV. Kemilau Ilmu Semesta.

Tafsir, A. (2008). Metodologi Pengajaran Agama Islam. Bandung: Remaja Rosdakarya. Umar, B. (2001). Ilmu Pendidikan Islam. Jakarta: Amzah.

Wijayakusuma, M. K., \& Yusanto, M. I. (2002). Menggagas Bisnis Islami. Jakarta: Gema Insani Press.

Yusuf, F. (2000). Evaluasi Program. Jakarta: Rineka Cipta. 